\title{
Public Participation As An Instrument Of Performance Of Eu-Funded Cross-Border Projects
}

\author{
Matej Pozarnik \\ Vesna Sotlar \\ ProFUTURUS d.o.o., Slovenia
}

doi: 10.19044/esj.2016.v12n11p111 URL:http://dx.doi.org/10.19044/esj.2016.v12n11p111

\begin{abstract}
The objective of the European territorial cooperation programme INTERREG has been financing joint projects of cross-border areas ever since 1990. Since many projects, financed in the past, did not provide longterm effects, the European Union decided to introduce the "result-driven approach" to these programmes. The realization of results will be consequently monitored during the project financing and after completion of selected projects. If one wishes to ensure sustainability also after the end of financing, the public and target groups must be actively involved in preparation and implementation of projects from the very beginning. The purpose of this paper is to present possibilities of public participation in different phases of the project. A comprehensive model of public participation was developed on the basis of research, involving the public into the sustainable life-cycle of a cross-border project.
\end{abstract}

Keywords: INTERREG, project, public participation, sustainability

\section{Introduction}

Cross-border programmes, implemented within the European Territorial Cooperation provide a great opportunity for financing the development of cross-border regions and organisations that operate in these areas. Cross-border calls for proposals can provide organisations with up to $85 \%$ co-financing of eligible project costs. Competition is harsh; only the best projects are selected for funding. Crucial in preparation of such projects is not only the set-up of the partnership, defining cross-border dimension and innovativeness, but also sustainability of the project. The key objective of cross-border programmes is improving the quality of life of residents in cross-border areas and increase attractiveness of the area with the purpose of attracting more visitors; one therefore needs to involve the public, too. 
The problem of the financial perspective 2007-2013 is that while the project selection process evaluated sustainability of projects, the latter was never realized in practice. Projects, once completed, were not monitored for sustainability. The result of inconsistency of monitoring sustainability of projects is that such projects do not have a long-term perspective, but rather live only during the time of EU financing. It is a fact that more than $80 \%$ of cross-border projects are an end in itself. The period 2014-2020 therefore sets a new concept for programme implementation.

The assertion of this article is that the condition for ensuring sustainable results in a project means public participation or involvement of target groups already in the project idea planning phase.

After extensive research of preparation and implementation of crossborder projects in financial perspectives 2000-2006 and 2007-2013, a Crossborder project lifecycle sustainability provision model was developed. Further research was focused on the element of public participation and its influence on ensuring sustainability and successful implementation of the project. The main findings show that projects involve the public mostly in the implementation phase, namely in dissemination of project results during the duration of the project; but they do not ask for public participation during the project preparation phase. The main objective of this paper is to present research results through the Cross-border project lifecycle sustainability provision model from the point of view of public participation.

We have explored the possibilities of public participation in all phases from planning the project idea onwards. When developing the Crossborder project lifecycle sustainability provision model with public participation, a descriptive method was used that described theoretical starting point of cross-border cooperation and public participation. The inductive method was used to formulate overall conclusions from findings, deriving from monitoring the implementation of individual cross-border projects. The method of data synthesis of cross-border projects and public participation presents possibilities for ensuring sustainability of cross-border projects as well as developing a new model of ensuring sustainability of cross-border projects.

Chapters "Cross-border cooperation" and "Public participation" present a theoretical foundation of cross-border cooperation and public participation. Research results are integrated in the Model of public participation in sustainable lifecycle of a cross border project, as presented in Chapter 3.

This comprehensive model is based on the assumption that the public (including target groups) must be actively involved in all project phases; from the project idea onwards. This is the only way to ensure successful implementation and sustainability also once the EU funds are terminated. 


\section{Cross-border cooperation}

Cross-border cooperation programs promote cooperation of organisations that operate in these areas through financing joint projects. The aim of cross- border cooperation is to solve common challenges, defined by cross-border regions. Cross-border activities (European Commission, Regional Policy, 2013a) are carried out in several beneficiary countries in areas where joint action leads to better and more effective results, contributing to a common goal: the process that leads the region's progress in each country and thus the progress of the Union as a whole.

The beginnings of cross-border cooperation go back to the year 1990 with the programme Interreg I that saw participation of 11 countries. In the second period (from 1994 to 1999) the number of participating countries increased to 15; during the third period (from 2000 to 2006) to 25; and in the fourth period (from 2007 to 2013) first to 27 and later to 28. The current programme Interreg V-A that will last from 2014 to 2020 (period V of the European Territorial Cooperation programme) includes all 28 member states of the EU. The programme is divided into 60 cross-border programmes that take place along 38 internal borders of the EU, 12 IPA programmes (Instrument for Pre-accession) and 16 Interreg ENI CBC programmes (European Neighbourhood Instrument). The budget for financing crossborder projects amounts to 6.6 bn EUR, IPA programme budget to 242 million EUR and ENI CBC programmes budget to 634 million EUR ( European Commission, Regional Policy, 2013b).

Cross-border cooperation of neighbour countries is defined in cooperation programmes. These are prepared in accordance with the strategic document Europe 2020 and partnership agreements between countries and the European Commission including the following three regulations:

- Regulation (EU) No 1299/2013 of the European Parliament and of the Council of 17 December 2013 on specific provisions for the support from the European Regional Development Fund to the European territorial cooperation goal,

- Regulation (EU) No 1301/2013 of the European Parliament and of the Council of 17 December 2013 on the European Regional Development Fund and on specific provisions concerning the Investment for growth and jobs goal and repealing Regulation (EC) No 1080/2006,

- Regulation (EU) No 1303/2013 of the European Parliament and of the Council of 17 December 2013 laying down common provisions on the European Regional Development Fund, the European Social Fund, the Cohesion Fund, the European Agricultural Fund for Rural Development and the European Maritime and Fisheries Fund and laying down general provisions on the European Regional 
Development Fund, the European Social Fund, the Cohesion Fund and the European Maritime and Fisheries Fund and repealing Council Regulation (EC) No 1083/2006.

Strategy Europe 2020 defines 11 thematic objectives through which the countries can finance EU Cohesion policy actions. ERDF contributes to thematic objectives in accordance with provisions of Article 5, Regulation (EU) No 1301/2013, as set in the first paragraph of Article 9, Regulation (EU) No 1303/2013. Article 7 of the Regulation (EU) No 1299/2013 of the European Parliament and of the Council of 17 December 2013 on specific provisions for the support from the European Regional Development Fund to the European territorial cooperation goal defines special provisions for supporting the goal "European Territorial Cooperation" from ERDF for the period 2014-2020; in addition to investment priorities set out in Article 5 of the Regulation (EU) 1301/2013, the following four priority actions can be co-financed within thematic goals, available to cross-border countries:

- Encourage sustainable and quality employment, supporting mobility of employees by connecting cross-border labour markets, including cross-border mobility, joint local initiatives in the area of employment, information and consultancy services and joint trainings;

- Promoting social inclusion and fight poverty and any other discrimination, promote gender equality, equal opportunities and cross-border integration of communities;

- Investing in education, training and vocational training for skills and life-long learning through developing and implementing joint schemes in the area of education, vocational training and training in general;

- Enhancing institutional capacity of public administration and interested public, efficient public administration through encouraging legal and administrative cooperation between citizens and institutions.

Agreement on selecting priority actions is set by participating countries considering the needs from cross-border areas. Once the countries have prepared a SWOT analysis, the content and other cooperation conditions are set and the cooperation programme prepared. This is then sent to the European Commission; once confirmed by European Commission, the countries receive a green light to start the programme implementation through publishing joint calls for proposals for selection of projects.

A characteristic of cross-border cooperation projects is participation from at least two participating countries (European Parliament and Council, 2013); partners establish a common way of work on the project; this includes joint development, joint implementation, joint staff and joint co-financing 
(Government Office for Local Self-Government and Regional Policy, 2010); activities are carried out in accordance with confirmed project application, programme reporting guidelines and guidelines for dissemination of results; project costs are refunded on the basis of content and financial reports, submitted to the Joint Technical Secretariat every 6 months. Partners might have to wait for cost refund for up to one year.

Cross-border projects provide partners with ambitious challenges that derive from inter-cultural differences and different customs. Another challenge can be the language. The study on how to overcome the main problems of cooperation, performed among mayors in the area Prachatice and Freyung-Grafenau (Stemberkova, 2013), suggests the change of generations, because the younger generation already knows its neighbour's language at least at the communication level. It is necessary to support meetings of mayors so that they can get to know each other and acknowledge their different professional orientation, problems, attitudes, mentality, etc. The other proposals on how to avoid problems, connected with joint cooperation included suggestions for building traffic communications, improvement of public transport and the possibilities of using free time (i.e. culture, sport and relaxation).

Cross-border programmes were based on cooperation of public and non-profit organisations. However, the last financial perspective (2014-2020) shows that the programmes are changing and now also enable cooperation of for-profit organisations. Promoting cross-border cooperation with the intention of developing cross-border areas is important not only among public administration but also among firms. Two steps are needed in order to increase cooperation among firms (Roper, 2007): first, steps could be taken to increase firms' understanding of cross-border market opportunities and business culture. Second, current policy initiatives to increase business R\&D activity, and strengthen firms' skill base are both likely to have indirect benefits in terms of increased cross-border co-operation.

The objective of cross-border cooperation programme is not only successful cooperation of partner organisations during the project financing, but also in ensuring long-term effects and sustainable results once the EU cofinancing ends. Efficiency and sustainability of cross-border projects depends mostly on public support, dissemination activities, informing the public about exploitation of project results that must be publicly available even after the EU financial support has ended. The distribution of project information in public contributes to securing financial, political and institutional support as well as to the acceptance of a project (Brand, Hollederer, Wolf, \& Brand, 2008). One therefore needs to provide more attention to public relations and public participation in all phases of the 
project life-cycle of cross-border projects, dedicated to ensuring a balanced regional development.

\section{Public participation}

One needs to check public opinion or the opinion of target groups already during the project planning phase in order to see if they are in favour of the planned idea/contents. Public opinion (Splichal, 2005) is closely connected to the term civil society. Civil society consists of organisations and activities without direct economic or political nature; those who are not motivated by profit and power. These serve as the basis for formation of ideas and objectives through which individuals or groups try to influence formation of opinions and decision-making within given institutional frameworks or even influence change on frameworks.

Public participation (André, Enserink, Connor, \& Croal, 2006) is defined as the involvement of individuals and groups that are positively or negatively affected by a proposed intervention (e.g. a project, a program, a plan, a policy), subject to a decision-making process or are interested in it. It is believed that levels of participation vary, from passive participation or information reception (a unidirectional form of participation), to participation through consultation (such as public hearings and open-houses), to interactive participation (such as workshops, negotiation, mediation and even co-management). Friesecke (2011) makes a distinction between legally binding public participation and non-binding public participation. When speaking about projects, the focus is on non-binding public participation that is not legally regulated and can be adopted differently according to the project theme.

One can check acceptance of project ideas in public or among target groups in several ways (Valicon, 2015): online questionnaire, telephone questionnaire, discussion (focus) group (discussion between 6 to 8 participants), field work, detailed interview with the researcher.

The public can be involved in the project also through intergovernmental working groups, workshops and public debate; all of which collect opinions of a wider public and target groups. Opinions can be collected through a particular form or via email.

Dimants, Sloka, Kleperis, Dimanta, Kleperis, Gudakovska, Tora and Univ (2012) list the following methods for obtaining public opinion: scientific publications research, evaluation of practical knowledge transfer and marketing tools application evaluations using questionnaire. Janse and Konijnendijk (2007) talk about information provision with information distribution (newsletter, website, contact and information office) and public events (information meetings, public exhibitions, information stands, public sensitization/awareness raising events, events dedicated to the presentation 
of project documents); information collection by social surveys/interviews and other surveys; involvement of experts and the public at large (sounding board group, public workshops, thinking days with the public, connoisseur approach - future managers meeting local connoisseurs, expert analysis, expert interviews, thinking days with experts and also involvement of children and youths with youth work-play happening, communication with children and teenagers through participation in practice and youth round table).

The following eight key approaches can be applied for obtaining public opinion in the field of science and technology policy (Rowe \& Frewer, 2000): referenda, public hearings / inquiries, public opinion surveys, negotiated rulemaking, consensus conference, citizens` jury / panel, citizen / public advisory committee and focus groups. The project leader of the project group obtains opinion through these tools in order to see if there is a need for a certain project in a certain cross-border area.

Public participation is also important in the project initiation phase. Informing the public and dissemination of project results are key factors that help the project to reach target groups. Kotler (Kotler, Čater, Bodlaj, \& Bajde, 2004) divides the most common communication tools in 5 main types of communication:

- Advertising (printed advertisements, TV and radio advertisements, back-side of packaging, leaflets in packaging, films, brochures and booklets, small posters and flyers, telephone directories, reprinted ads, jumbo posters, displays, audio-visual material, symbols and logotypes, videotapes);

- Sales promotion (prize contests, samples, trade fairs and exhibitions, displays, presentation of products, coupons, special sales promotions, low-interest loan, events, selling “old for new”, loyalty programmes, contract purchases);

- Public relations (press materials, speeches, seminars and workshops, annual reports, charity work, sponsorships and donations, press releases, relationships with the local community, lobbying, corporate identity, newsletters, events);

- Personal selling (sales presentations, sales meetings, incentives, samples, trade fairs and exhibitions);

- Direct marketing (catalogues, direct mail, telephone sales, online shopping, TV sales, telefax messages, email, voice mail).

The European Union encourages organisations in co-financed projects as well as member states in general to include the public in all areas in order to disseminate information to the widest possible audience. The EU also signed the Aarhus Convention (Marega \& Kos, 2002) on Access to Information, Public Participation in Decision-making and Access to Justice 
and Environmental Matters. This international agreement enables individuals and organized groups to play an important role at safe-keeping the environment and promotion of sustainable development. The European Commission also sets rules and regulations about informing the public about projects, co-financed by the European structural funds. Each programme has defined rules for informing the public, which must be considered by all beneficiaries.

The European Union furthermore requires that all research results, financed with public funds, have to be publicly accessible.

There are two main routes (European Commission, DirectorateGeneral for Research \& Innovation, 2013) towards open access to publications. The first option is Self-archiving (green open access) where the published article or the final peer-reviewed manuscript is archived (deposited) by the author - or a representative - in an online repository before, alongside or after its publication. Repository software usually allows authors to delay access to the article (embargo period). For green open access (Spichtinger, 2013) there is an extensive established infrastructural support (e.g. OpenAIRE); it is cost effective, supportive of authors across all disciplines, delivers for funders and is publisher friendly. The second option for open access is called Open access publishing (gold open access) where an article is immediately provided in open access mode as published. In this model, the payment of publication costs is shifted away from readers (via subscriptions) to authors. The business model most often encountered is based on one-off payment by authors. These costs (often referred to as Author Processing Charges, APCs) can usually be borne by the university or research institute to which the researcher is affiliated, or to the funding agency supporting the research. In other cases, the costs of open access publishing are covered by subsidies or other funding models.

There are different instructions for informing the public for each individual cross-border programme. Cross-border projects between Slovenia and Austria that were carried out within the perspective 2007-2013 (Government Office of the Republic of Slovenia for Local Self-Government and Regional Policy, 2011) asked all beneficiaries to use the main graphic elements (programme logotype and logotype of the EU), including the statement that the operation was partly funded by the European Union with reference to the European Regional Development Fund and the slogan "Investing in your future". Information and publicity guidelines also provide guidelines on organization of press conferences and other events, related to the project, including press releases, information on webpages of the beneficiary and marking of written materials and other documents that are generated through the project. There are furthermore instructions about how to mark construction sites or bulletin boards, other signage and labels. In 
case of larger infrastructure, the construction site must have a clear display of the project and the source of financing.

\section{A model for ensuring a sustainable lifecycle of cross-border projects with public participation}

Ten years of research and management of cross-border projects show that such projects usually do not ensure sustainability of results after the project completion. Therefore a Model for ensuring a sustainable lifecycle of cross-border projects was developed (Požarnik \& Sotlar, 2015). Further analysis showed that the main reason for the lack of sustainability was insufficient participation of target groups and wider public throughout the project lifecycle, including the project idea design.

The model included cooperation of the project group with the public through all project phases:

- Basic project phase: project idea, project proposal, financing, implementation, upgrading and sustainability-oriented funding;

- Parallel phases that must be carried out through the whole project duration: public participation, monitoring and evaluation, and sustainability.

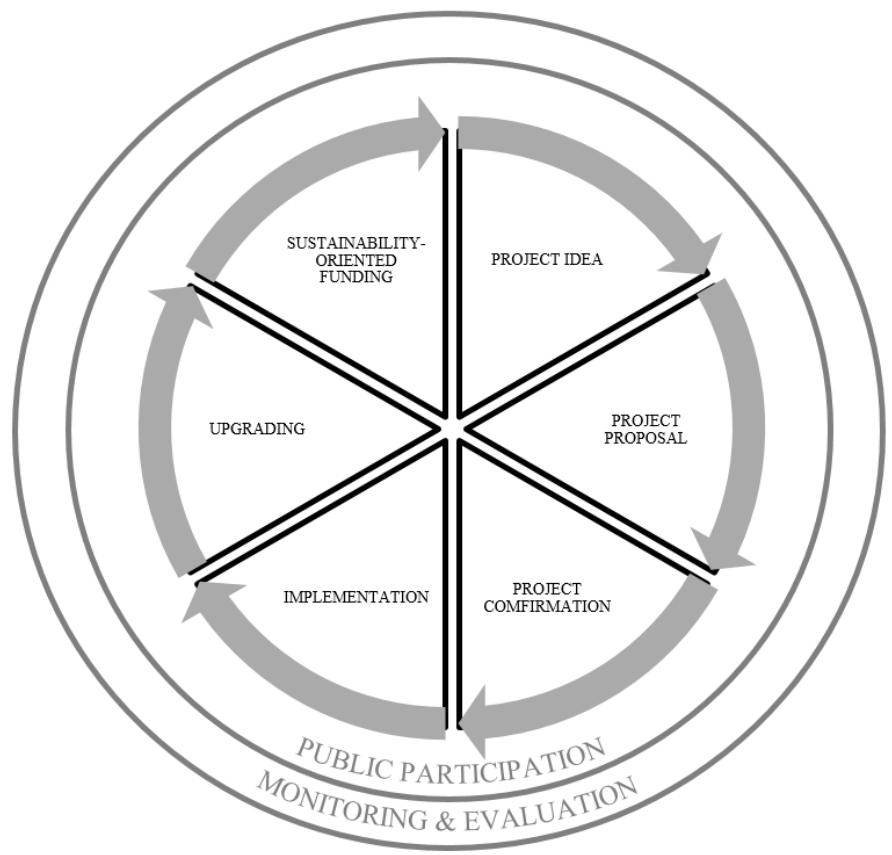

Figure 1: Model of public participation in the sustainable lifecycle of the cross-border project. 
Public participation in a cross-border project already starts with the project idea, when partners on both sides of the border prepare a project outline on the basis of "as-is" analysis. Given that the cross-border programmes aim to ensure a balanced regional development, one needs to analyse the need for a concrete project idea in the local and regional environment. A project can be successful and have long-term effects only with a wide public support, or support of target groups. Figure 2 shows a graphic example of public participation in individual phases of project lifecycle.

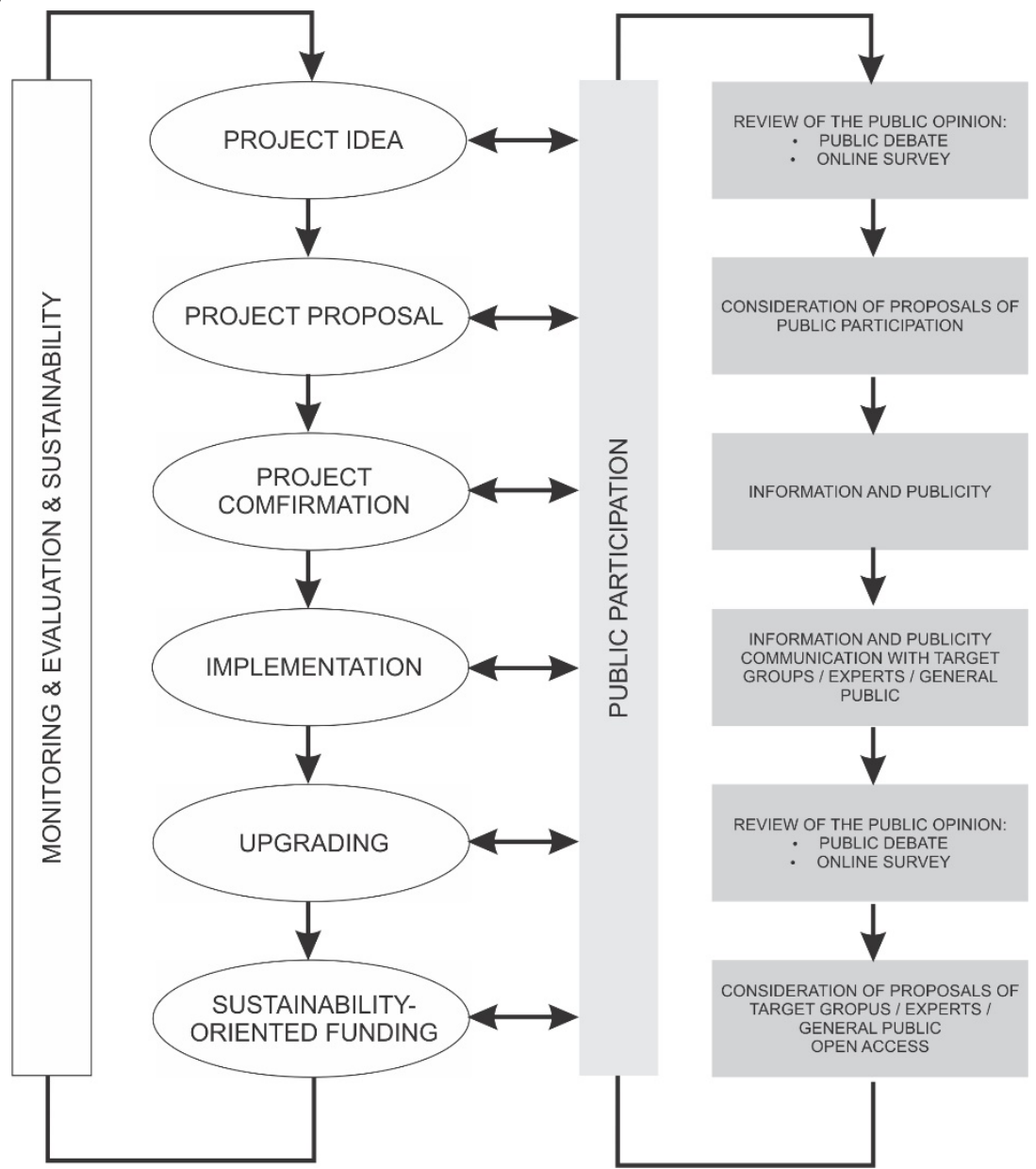

Figure 2: Communication tools for public participation according to individual phases of a sustainable lifecycle of a cross-border project.

\section{Phase 1: Project idea}

Project idea development starts with the analysis of needs, opportunities and challenges on both sides of the border (on the basis of existing studies, reports and other documents). The project group develops the project idea on the basis of analysis; the idea must be presented and 
checked among target groups / public (professional and wider). This can be done with help of different tools; research then shows if the project idea is supported among target groups and the public in the selected cross-border region. The following tools can be used for checking the project idea:

- Regional workshops with target groups of 15-25 participants,

- Online and field survey checks opinions of individuals that will be affected by the project through questionnaires (field work and online solutions).

Analysis of obtained data is used for preparation of the final project idea with a draft of an action plan for ensuring sustainability of project results.

\section{Phase 2: Project proposal}

In the second phase (once the call for project proposals has been issued) the project group adjusts the contents of the project idea to the conditions and guidelines of the call for proposals, considering the results, obtained from the public. Prepared project proposal must clearly show the importance and benefits for a wider public.

Project preparation phase must also include detailed information and publicity activities as well as tools for exploitation or project results. One needs to include as many communication tools as possible that will enable the project partnership to check among all target groups and the public if the project is delivering planned outcomes; this should be available and checked at all times during the course of the project. Cross-border projects must therefore have a separate work-package called Communication and dissemination.

Table 1: An example of the work-package Communication and dissemination within a cross-border project (without the number of outputs).

Kick-off conference:

- Preparation of invitations for the media, professional and wider public.

- Organization of a press conference where the project contents is presented to the media (TV, radio, newspapers, journals, online media).

- Organization of the main event with the programme: presentation of project partners and activities, including planned project events (inviting target groups and professionals to participate in interactive project contents).

Graphic design - Project brand guidelines:

- Designing the logotype and project templates.

Project web-page:

- Presentation of project contents.

- Presentation of project partners.

- News and announcements on project activities / events.

- Opinion polls and data collection. 
Facebook profile of the project:

- Presentation of project contents.

- Presentation of project partners.

- News and announcements on project activities / events.

- Checking public opinion about individual activities and events.

Leaflets, brochures, posters and other printed media:

- Design and print of materials.

Media publications:

- Publications on TV, radio, online media, ...

- TV interviews.

- Short TV commercials.

Promotion material:

- Promotion T-shirts, caps, pens, USB sticks, umbrellas, notepads, bags ... that is distributed at promotion events.

Fair:

- Presenting the project at specialized fairs with the project-related theme.

Exhibit:

Film:

- Organising an exhibit with presentation of project results.

- Making a short film about project activities and results.

Other promotion events about project activities:

- Presentation of the project and project activities in local communities / schools...

- Organization of social events on project topic.

- Street events with animation programme.

Elements of communication with the public, target groups and professionals must also be involved in the work packages of the project proposal.

Table 2: An example of including information and publicity elements into a contextual work package (without the number of outputs).

\begin{tabular}{l} 
Interactive events: \\
\hline - Organization of professional cross-border conferences; the first part includes \\
presentation of professionals and their view on the project; the second part is an \\
interactive debate among professionals, target groups and wider public about \\
project activities and their results. \\
- Organization of workshops with target groups / professional public / wider public \\
with the intention of exchanging information between the project group and the \\
public and obtaining suggestions for continuation of project activities. \\
- Organization of an online conference in the form of written materials that will be \\
commented by the target group and the professional and wider public. Results of \\
the online conference are integrated in further project activities.
\end{tabular}

Once the project proposal is finalized, the group submits the application and awaits evaluation of the evaluation committee and the managing authority of the programme. 


\section{Phase 3: Financing}

The project is approved for financing, the co-financing contract is signed with the managing authority, and so are the partnership agreements. The managing authority informs the public at its webpage about selected projects that will be co-financed from public funds. Project partners inform their target groups and public about the selected projects on their own webpages, through conferences, work meetings and other online media.

\section{Phase 4: Implementation}

Project implementation starts according to the plan from the approved project proposal. All project activities that lead to realization of goals, milestones and project results must be carried out. In this phase, the project partners prepare a concrete action plan for implementation of project activities, followed by management, coordination and implementation of project activities as agreed between partners. Also included is participation of the public and target groups, and coordination with the contract administrator at the managing authority.

Information and publicity activities are carried out at different levels:

- Managerial structure of the cross-border programme: project partners prepare interim reports and the final report to inform the managing authority of the cross-border programme about activities. They are also invited to the project events; their role can be active or passive. The managerial structure also monitors if all required procedures regarding information and publicity activities have been met.

- Professional public is informed about project activities through communication tools that are presented in tables 1 and 2. The project group has an active exchange of information with the professional public.

- Wider public: wider public is included in all information activities through communication tools, presented in tables 1 and 2.

- Target groups: are actively involved in all project activities since they are the ones that the project is meant for.

Project partners monitor and adjust the action plan throughout the project duration in order to ensure sustainability of project results also after the project completion. Activities are adjusted with opinions and suggestions of target groups, professional and wider public. The project group must also ensure that the possible research results of the project be publicly available at project end for further research of the discussed topic. 
Table 3: An example of open access to research results of the project.

Cycling activities at the cross-border area - situation analysis:

- Preparation of a written version of the research that will be available at the local tourism information centre, in the local and regional newspaper,

- $\quad$ E-version of the said research, available on the project website,

- "Green open access" - preparation of a professional peer-reviewed article on the topic of performed research within the project. Green open access means that the author's peer reviewed article has been accepted for publication in a scientific journal, but a copy is saved in the repository. By doing so, the author transfers the copyright for publication in the scientific journal to the publisher, herewith allowing the peer-viewed article to be saved in the author's final form to the repository (Social Sciences Repository, accessible at http://www.ssoar.info/en.html). This means that the article is available for permanent use in the repository for further usage in new projects.

\section{Phase 5: Upgrading}

The final phase of the project that has been co-financed by the crossborder programme includes a plan for upgrading the project activities for further use and to ensure sustainability. This again must be adjusted with target groups, professional and wider public; it must consider the opinions, gathered in Phase 4 of the project, especially in the part, referring to organizing interactive events. This is a particular part of the action plan that ensures sustainability of project results. I.e.: if the project is meant to coordinate cooperation of two cross-border tourism organization and set-up a cycling path, the target groups include tourism providers on both sides of the border and potential tourists who visit this area. In case the cross-border tourism providers wish to organize an annual cycling marathon in this area, that would attract participation from all around the world, it makes sense to direct project activities into this content. It furthermore makes sense to check the opinion of the local inhabitants, tourists and cyclists. This will ensure sustainability of project activities and results through considering opinions of target groups, professional and wider public. If more people use the cycling track, the action has a wider positive influence on gastronomy, tourism, local crafts, sports and similar activities in the area, which also raises income of the local population.

Adding new contents and enlarging the network of project partners the project group can prepare a new project proposal for a new call for project applications; new funds can be obtained, consequently improving the quality of life of the local population and a higher level of prosperity.

\section{Phase 6: Sustainability-oriented funding}

This phase defines the actual sources of co-financing that will enable sustainability of project results after the project financing from cross-border 
funds terminates. The key issue in this phase is involvement of target groups, professional and wider public in preparation of the sustainability plan. They are the ones that must show interest for continuing activities. The employees who found work in jobs, created through the project, must show initiative to find new resources of co-financing after the project completion. They have to inform target groups, professional and wider public as well as search for new project partners about their initiatives and look for institutions that could contribute toward sustainability of the project.

Sustainability-oriented funding has several different possibilities: if the action plan for ensuring sustainability of project results is successful, the project financing could continue from project activities. The example from the cycling route: target groups (local tourism providers) organise monthly events in addition to the annual cycling marathon. These events can last for a week, such as a wine-week, a week of home-made culinary delicacies, etc.

Providers from the area of the cycling path join forces, take care for promotion and increase the number of visitor and awareness of the area. Due to a larger number of visitors, the income of the local population increases, enabling further financial input for financing sustainability of the project. In addition to that, the project partners search for further financial resources for upgrading the project activities. This includes analysing open calls for applications, and checking suitability of these calls, feasibility of cofinancing project activities and preparation of a new project proposal. This means that the funds are obtained from market activities and European structural funds.

\section{Conclusion}

Cross-border projects, co-financed with EU funds, enable regional development and provide a wider public benefit for target groups and the whole cross-border area that is affected by project activities. Wanting a successful and effective project means including target groups, professional and wider public. A project that wants to be sustainable and successful must be made for "the field", and not only written on paper and for project partners.

Public participation is important throughout project activities and not only from the point of view of dissemination of project results. One must determine the position and opinion of the civil society toward the project topic already in the project idea development and preparation phase. The project must be ethical and socially acceptable. It must ensure sustainability. Cooperation and joint efforts of the project team, professionals, target groups and the wider public is therefore the most important element for long-term success and sustainability. 
Most suitable approach for public participation is anticipatory approach. Project preparation starts with reviewing the existing literature and checking the actual needs for the project through active involvement of stakeholders and through different communication tools (focus groups, regional workshops, etc.). By doing so, one can determine their worries, needs and expectations, which is the basis for analysis of the "as-is" situation, defining the potential project market, risks and possibilities for its sustainability and other social aspects.

The purpose of cross-border programmes, co-financing cross-border projects is to set-up long-term partnerships that will be the foundation for a long-term joint development of cross-border regions. According to findings of Søderberg, Krishna and Bjørn (2013), the most important influence on setting-up long-term strategic partnership is the one of the senior management commitment and employee identification with the development projects, mutual trust and transparency in the collaborative work processes, and cross-cultural understanding and sensitivity as capabilities to bridge across national borders and organizational divides. One must therefore consider the said findings if wishing for a successful completion of a project. Another project element is interdisciplinarity that shows wider benefits, not only related to the project contents, but also a wider public benefit in different areas of operations. The interdisciplinary area of cross-border projects is also the topic for our future research work.

\section{References:}

André, P., Enserink, B., Connor, D., \& Croal, P. (2006). Public Participation International Best Practice Principles. Retrieved from http://www.iaia.org/publications-resources/downloadable-publications.aspx. Brand, H., Hollederer, A., Wolf, U., \& Brand, A. (2008). Cross-border health activities in the Euregios: Good practice for better health. Health Policy, 86(2-3), 245-254. doi:10.1016/j.healthpol.2007.10.015.

Dimants, J., Sloka, B., Kleperis, J., Dimanta, I., Kleperis, J., Jr., Gudakovska, M., Zelgalve E. (2012). OPPORTUNITIES FOR HYDROGEN MARKETING - PUBLIC OPINION ANALYSIS. New Challenges of Economic and Business Development - 2012, 131-141.

European Commission, Directorate-General for Research \& Innovation. Guidelines on Open Access to Scientific Publications and Research Data in Horizon 2020. (2013). Retrieved from

http://ec.europa.eu/research/participants/.../h2020-hi-oa-pilot-guide_en.pdf.

European Commission, Regional Policy. (2013a). Retrieved from http://ec.europa.eu/regional_policy/cooperate/cooperation/index_en.cfm. 
European Commission, Regional Policy, 2013b). Retrieved from http://ec.europa.eu/regional_policy/en/policy/cooperation/europeanterritorial.

European Parliament and Council. Regulation (EU) No 1299/2013 of the European Parliament and of the Council of 17 December 2013 on specific provisions for the support from the European Regional Development Fund to the European territorial cooperation goal, (2013). Retrieved from http://eur-lex.europa.eu/legal-content/EN/TXT/?uri=celex\%3A32013R1299. Friesecke, F. (2011). Public Participation in Urban Development Projects a German Perspective. Retrieved from www.fig.net/pub/fig2011/ppt/ts03d/ts03d_friesecke_4868_ppt.pdf. Janse, G., \& Konijnendijk, C. C. (2007). Communication between science, policy and citizens in public participation in urban forestry - Experiences from the Neighbourwoods project. Urban Forestry \& Urban Greening, 6(1), 23-40. doi:10.1016/j.ufug.2006.09.005.

Valicon. Vrste raziskav. (2015) Retrieved from jazvem.si/sl/raziskave.html. Kotler, P., Čater, B., Bodlaj, M., \& Bajde, D. (2004). Management trženja. Posušje; Ljubljana: Mate; GV založba.

Marega, M., \& Kos, D. (2002). Aarhuska konvencija v Sloveniji: strokovna priporocila za implementacijo Konvencije o dostopu do informacij, udelezbi javnosti pri odlocanju in dostopu do pravnega varstva v okoljskih zadevah. Ljubljana: Regionalni center za okolje za srednjo in vzhodno Evropo.

Spichtinger, D. (2013). Open Access policy in the European Research Area and beyond, 5th Conference on Open Access Scholarly Publishing (COASP 2013). Retrieved from http://www.slideserve.com/gordy/open-access-policyin-the-european-research-area-and-beyond.

Požarnik, M., \& Sotlar, V. (2015). Critique of the traditional cross-border cooperation project communication lifecycle model. Informatologia, Vol. 48 No.1-2.

Roper, S. (2007). Cross-border and local co-operation on the island of Ireland: An economic perspective. Political Geography, 26(5), 554-574. doi:10.1016/j.polgeo.2007.04.002.

Rowe, G., \& Frewer, L. J. (2000). Public participation methods: A framework for evaluation. Science Technology \& Human Values, 25(1), 329.

Soderberg, A.-M., Krishna, S., \& Bjorn, P. (2013). Global Software Development: Commitment, Trust and Cultural Sensitivity in Strategic Partnerships. Journal of International Management, 19(4), 347-361. doi:10.1016/j.intman.2013.04.004.

Služba Vlade Republike Slovenije za lokalno samoupravo in regionalno politiko, (2010). Program čezmejnega sodelovanja Slovenija-Madžarska 
2007-2013, Priročnik za izvajanje projektov. Retrieved from http://www-sihu.eu.

Government Office of the Republic of Slovenia for Local Self-Government and Regional Policy. Navodila za informiranje in obveščanje javnosti za upravičence za program evropskega teritorialnega sodelovanja, Operativni program Slovenija-Avstrija 2007-2013. (2011). Retrieved from http://www.si-

at.eu/projects_sl/category/information_and_publicity_guidelines_for_benefic iaries/.

Splichal, S. (2005). Javno mnenje: teoretski razvoj in spori v 20. stoletju. Ljubljana: Fakulteta za družbene vede.

Stemberkova, R. (2013). Cross-border cooperation: a case study of the districts of Prachatice (CZ) and Freyung-Grafenau (D). Geograficky casopis, 65(No. 4). 